\title{
Michelangelo, Copernicus and the Sistine Chapel
}

\author{
Valerie Shrimplin \\ Independent Art Historian, Gresham College, Holborn, London EC1N 2HH, England \\ Email address: \\ vshrimplin@dsl.pipex.com (V. Shrimplin),v.shrimplin@gresham.ac.uk (V. Shrimplin)
}

\section{To cite this article:}

Valerie Shrimplin. Michelangelo, Copernicus and the Sistine Chapel, American Journal of Astronomy and Astrophysics. Vol. 1, No. 1, 2013, pp. 1-7. doi: 10.11648/j.ajaa.20130101.11

\begin{abstract}
It is argued that Copernican astronomy is a key theme in Michelangelo's fresco of the Last Judgment in the Sistine Chapel, and was incorporated with the knowledge, consent and approval of the Popes concerned. In Christian art, the iconography of the Last Judgment (depicting the three parts of the universe: heaven earth and hell) was traditionally based on a layered structure relating to perceptions of the flat earth covered by the dome of heaven according to biblical cosmology. In Michelangelo's revolutionary work, Christ is significantly depicted as a beardless Apollonian sun-god, positioned in the centre of a dramatic circular design rather than at the top of a layered format. This appears to relate to the traditional Christian analogy between the deity and the astronomical feature of the sun, the neoplatonic cult of sun-symbolism and sources in Dante. More importantly, the influence of the Copernican theory of heliocentricity is argued, since interest in such ideas in papal circles is demonstrated at exactly the time of the commission of the painting (1533). This provides important evidence of papal support for Copernican heliocentricity as early as the $1530 \mathrm{~s}$.
\end{abstract}

Keywords: Copernicus, Michelangelo, Heliocentric, Sistine Chapel, Dante

\section{Introduction}

It has long been widely recognized that in Michelangelo's fresco of the Last Judgment (1541) Christ is depicted as a classical, beardless 'Apollonian' sun-god in the centre of a 'cosmic' circular design. The possible influence of Copernicus's theory of heliocentricity as a contributory factor to Michelangelo's interpretation has been considered by art historians, but consistently been rejected on the grounds that Michelangelo's fresco was finished in 1541, two years before the publication of Copernicus's Revolutions in 1543. The idea has thus always been dismissed without full exploration and consideration. Art historians have seemed hesitant to delve into astronomical texts, and astronomers are perhaps less familiar with Renaissance frescoes. This interdisciplinary paper (which is a summary of the publication Shrimplin, V. Sun-symbolism and Cosmology in Michelangelo's Last Judgment, Truman State University Press, 2000) presents the argument that, although not definitively provable in a scientific sense, it can indeed be argued that Copernican heliocentricity is reflected in Michelangelo's fresco.

The Sistine Chapel, part of the complex of St Peter's in Rome, was built in 1475 on the site of an earlier thirteenth century chapel. Cosmological associations of the chapel are immediately evident since it measures 40.93 metres by
13.41 metres wide (threescore cubits by twenty cubits), that is, the precise dimensions given in the Bible for the temple of Solomon (1 Kings 6), which in turn was widely held to have been made in imitation of the shape of the universe.

The Chapel ceiling (painted by Michelangelo 1508-12) [1] is well known for the depiction, according to Genesis, of the creation; of light and dark; of the universe; and the planets and humanity. On the altar wall, Michelangelo's monumental fresco of the Last Judgment (painted much later, 1536-1541) depicts, by contrast, the end of the universe. The overriding theme of the Chapel is thus 'the Beginning and the End' - of the universe, the planet and humanity. Interpreted in terms of 'Creation and Last Judgment', rather than the modern 'Big Bang and gravitational collapse', the problems remain the same to be grappled with, even if the solutions or interpretations vary. But the overriding cosmic theme of 'the beginning and end of the world' is clear in Michelangelo's frescoes in the Sistine Chapel.

Situated over the altar wall in the most important chapel in Christendom, Michelangelo's fresco of the Last Judgment could well lay claim to being the single most significant painting in the world and the immense importance of the fresco was immediately recognised by Michelangelo's contemporaries. Almost as soon as it was completed and 'unveiled' on All Saints' Eve, 31 October 1541, Michelangelo's Last Judgment became a focus for controversy as well 
as admiration. Michelangelo's contemporary the Venetian critic Pietro Aretino was not alone in his comments on its allegorical and hidden meaning, when he observed in 1545 that 'Michelangelo has imitated those great philosophers who hid the mysteries of human and divine philosophy under a veil, that they might not be understood by the vulgar'. Literally hundreds of writers have attempted to 'decode' and explain the fresco and its hidden symbolism ever since. [2]

\section{Cosmology in Church Art and Archi- tecture}

The main argument presented here is that Copernican astronomy is a key theme in the fresco, and was intentionally incorporated by Michelangelo, with the knowledge, consent and approval of the popes concerned. Judaeo-Christian cosmology, or the view of the universe, was traditionally reflected in Church art and architecture, for example in Early Christian and Byzantine domed architecture, which was imitative of natural eye perceptions of the flat earth covered by the dome of heaven. Decoration and decorative cycles (as at the Dome of the Rock, Jerusalem) confirm a symbolic approach, with blue or starry vaults confirming the intention to represent the heavens rather than simply create a covering for a space in such examples.

Apart from Church architecture in general, particular subjects from the scriptures also lent themselves especially well to cosmological interpretation. This was particularly relevant in version of the Last Judgment as the one scene in Christian theology where Heaven, Earth and Hell (the three parts of the known world) together with their relative physical positions in the cosmos would naturally be depicted at one time, together. Complex ideas concerning heaven, earth and hell, and the fate of humanity, were illustrated together in a single image, in a distinctly layered design. In innumerable examples of the Last Judgment, the three parts of the known universe would be depicted in relation to the hierarchical order, according to which all would be judged - as the 'good' would ascend to heaven as the 'bad' would be sent down into hell - creating a strong disciplinary message in the absence of widespread effective judicial systems.

\section{Michelangelo and the Sun-Christ Analogy}

Michelangelo's dramatic circular design, focussed on the central figure of Christ depicted as a beardless 'Apollonian' sun god varies enormously from the layered and hierarchical approach in traditional versions of the Last Judgment. It contrasts dramatically with numerous previous versions from medieval and early Renaissance times, exemplified by the sculptural versions in Romanesque and Gothic cathedrals or in Italian Renaissance examples where the arrangement is consistently layered in a horizontal format with Christ at the top of the hierarchical design. In compar- ison, Michelangelo's fresco is predominantly circular in design, with Christ, depicted as the sun, at centre.

Lines which could be construed as descriptive of Michelangelo's fresco:

"In the midst of all assuredly dwells the Sun. For in this most beautiful temple who would place this illuminary in any better position ... some call him the Light of the World .... So he remains, governing the family of Heavenly bodies which circles around him"

actually come from Copernicus's Revolutions, Book 1, chapter 10 [3] Yet Copernicus' book was published in 1543, two years after the great fresco was completed and clearly many years after it was commissioned and designed. Because of the discrepancies in the dating of De Revolutionibus and the dating of Michelangelo's fresco, the possibility of a link between the two was never seriously and fully explored.

The art historian Charles de Tolnay wrote (1943-60):

"By means of the central place which Michelangelo reserved in his composition for the Sun (Christ-Apollo) .. The artist came of himself to a vision of the universe which surprisingly corresponds to that of his contemporary Copernicus. Yet he could not have known Copernicus' book which was published in 1543 - at least seven years after Michelangelo conceived his fresco." [4]

The analogy between Christ and the Sun and the possible influence of Copernicus' theory was seen as impossible because the publication date of the book postdated the completion of the fresco. However if we look at the sort of sources used by Michelangelo - Christian theology, classical and Christian iconography, Dante, neoplatonism and, it will be argued, contemporary scientific theories, a case can be made for the undoubted influence of Copernicus' heliocentric theory on the fresco.

Typical images of Apollo, such as the Apollo Belvedere (Greek, 2nd century BC, found in Italy in 1489), had been common in the Italian Renaissance. Many such examples were rediscovered in Renaissance Florence and Rome at the time when Michelangelo was working in those cities. An affinity with this type of image is very clear in Michelangelo's design. The concept of Christ as an Apollo-type figure was common in the very early days of Christianity, as a way of encouraging converts - and the idea of Christ as the sun or the light of the world is demonstrated by innumerable biblical references (particularly in the Gospel of St John, especially 1:1-10 and 8:12).

\section{Astronomy and Iconography}

The links between astronomy and Christian iconography and decoration can also be securely established, for example in the starred, domed ceiling mosaic of the mausoleum of Galla Placidia at Ravenna (c. 425) which echoes the flat earth view, covered by the dome of heaven. [5] The mosaic of God creating the world at Monreale (1175) is another instance where the cosmic meaning is clear, and the creation cycle in St Mark's Venice (11th century) also demon- 
strates the view of the cosmos in relation to its creation as a strong part of the Christian tradition. These examples cited (of which there are innumerable others) serve to demonstrate the important links between Christian iconography and astronomy. Another area is that of the orientation of Christian architecture. The east-west orientation of Christian Churches, with the altar in the east, is well known, and evidenced by Christian Churches of all regions and periods. The basilica of St Peter's in Rome is exceptional however since, situated to the west of Rome, the entrance faces Rome itself to the east. Few churches have their altars in the west, but it seems that the reason for this at St Peter's was because the original basilica was built by the Emperor Constantine on the earlier foundation of a pagan sun temple where the aim was for the rising sun to enter the doorway. The Last Judgment in turn was normally placed on the west wall of a church, to face the setting sun at the end of the day. It was also located in that area in the west, as a stern reminder to the congregation on exit. The Sistine chapel has the same orientation at St Peter's so Michelangelo's Last Judgment is unusually placed on the west (but significantly the altar) wall of the chapel, where its presence is again a potent reminder of the end of the world and the fate of humanity. The 'good' however will have nothing to fear.

Before the Sistine chapel (begun the year Michelangelo was born) was redecorated in late fifteenth and early sixteenth century by Michelangelo and others, it was known to have been decorated with a simple blue ceiling covered in stars, thus again establishing an astronomical connection. In addition, the links between the concept of the Last Judgment and the arrangement of the known universe were also extremely well established. A good example is the sixth century manuscript by the Syrian monk Cosmas Indicopleustes in his Christian Topography. [6] This includes a version of the Last Judgment with Christ situated at the top and various ranks of humans, saints and angels ascending to heaven and descending to hell in a strict hierarchy. Significantly, there is a drawing of the universe in the same manuscript which clearly relates to the same layered format, showing an immediate and obvious relationship between the view of the universe and the concept of the Last Judgment. Apart from manuscript versions, this basic format for the Last Judgment can be seen, as mentioned, in innumerable examples, in the tympana of the great French cathedrals (for example Vezelay, 1125, Notre Dame, completed 1250), and in earlier Italian frescoes, such as Giotto's version at Padua (c 1305-7) or altarpieces by Fra Angelico (1440) to name just a few examples. The hierarchical framework is very clear in Giotto's work, in spite of the intrusive window. But Michelangelo changed all this in his version, introducing a revolutionary new design. There are features of the old traditions still remaining in Michelangelo's work but he had the existing window filled in, so as to make one vast space. As a result, a huge circular design predominates across the entire altar wall. The circular motion overcomes and warps into the traditional layered features of the iconography of the design of the Last Judgment.

\section{Dante's Cosmology}

At this point it is important to remember the idea of the centre of the universe. According to Judaeo Christian tradition, this was held to be Jerusalem in the flat earth system in accordance with Ezekiel 5:5. This is clearly illustrated in many so-called T-and-O maps, but there is evidence that the old idea of the sun-centred universe, as proposed by the ancient Greeks, such as Aristarchus, never completely died out. [7] The 'astronomer' Pope Gerbert, for example, had raised such ideas in c. 999. However, in general, it was the geocentric concept of the earth that displaced the flat earth view of the universe in Western Europe in the middle ages, as illustrated in fifteenth century Florentine manuscripts (such as the Diagram of the Cosmos 1038, 240v in the Biblioteca Riccardiana, Florence). This new geocentric view was generally perceived by educated persons, yet the problem here was that if the idea of a circular universe with the earth at the centre was combined with the Biblical concepts of 'up for heaven' and 'down for hell' then hell would appear to take the central place in a 'haidocentric' universe. This was clearly unacceptable and somewhat difficult to deal with. Dante therefore, in his Divine Comedy therefore selects a 'dual' scheme for his universe, with two systems separately presented: one for Inferno (centered on Hell) and a separate scheme for Paradiso (centered on the Heavens). Dante, and his illustrators, firstly presents a terrestrial system with Lucifer at the centre (as in the manuscript of the Topography of Hell, Florence c 1475, Biblioteca Nationale, Palat 320, fol.IIIv). In fact, the precise centre of hell is defined in Inferno 34 as the point at which Dante and his companion Virgil descend down the figure of Lucifer, then turn (at the point of Lucifer's thigh) in order to start ascending again towards the surface of the earth's sphere. This view of hell in the centre of the earth or terrestrial system contrasts with Dante's separate circular system in the Empyrean, focussed on a point of light - as depicted in, for example, Botticelli's illustrations for the Divine Comedy as a 'sun-Christ' type of figure or symbol.[8]

Michelangelo was well known as an expert on Dante and would undoubtedly have been familiar with Dante and the issues that were raised here. His own poetry and that of his friend Vittoria Colonna also include very many references to Christ as the sun - and, lest any complex association be dismissed, it is important to remember that Michelangelo always avowed 'I paint with my brains, not with my hands.' Whilst it is inappropriate to read too much into artistic work, it is similarly incorrect to underestimate artists of the stature of Michelangelo.

\section{The Neoplatonic view of the Universe}

Turning now to other contemporary ideas that would have been considered in this period, the importance of neoplatonic philosophy should not be underestimated. Michelangelo - growing up as he did under the patronage of Lorenzo de Medici - was also an expert on neoplatonism 
and the works of Marsilio Ficino.[9] Until Ficino translated Plato's oeuvre from the Greek, few of Plato's works had been known through the medieval period. The exception was Plato's Timaeus which is well know for its theme of cosmology. He wrote, 'Seeing that the whole is spherical, the assertion that it has one region 'above' and one region 'below' does not become a man of sense' (Timaeus 63). The importance of this work in the early sixteenth century is demonstrated by the fact that in Raphael's famous School of Athens, the figure of Plato holds this very volume under his arm. Michelangelo would therefore have been familiar with works by neoplatonic philosophers such as Ficino, Poliziano and Landino, which focus on interpretations of Plato's cosmology. The writings of Marsilio Ficino are a major source for the symbolic identification of the Sun and deity as repeatedly found in Renaissance literature and philosophy. Probably Ficino's most important work, and one which Michelangelo is known to have been familiar with, is his Commentary on Plato's Symposium. The neoplatonic idea of the sun as symbol of the deity as well as the cosmological ordering of the universe are fully examined by Ficino. In Chapter 2, Part II of the commentary, he draws a direct comparison between this theme and Plato's writing in the sixth book of Plato's Republic where the concept of the light as the Good is fully explained by Plato. Early neoplatonic interpretation of Republic VI has also been argued as influential on St John's Gospel, the so-called 'Gospel of light'. Ficino continuously draws analogies between God and the sun which suggests his work as source material for Michelangelo. In addition, in fact, Ficino's ideas were also said to have influenced Copernicus Since his book De Sole was required reading in Krakow when Copernicus was a student there. [10]

\section{Copernicus' Theory of Heliocentricity}

Set against this context of Renaissance scholarship, it is important to remember that Copernicus was exposed to and influenced by these ideas since he spent at least seven years in Italy in a very similar environment to Michelangelo, and this is also demonstrated in his writings which include references to sun symbolism and neoplatonic ideas.[11] As mentioned, the idea of any relation between Copernicus' ideas on the sun-centred nature of the universe and Michelangelo's 'sun-deity' centred fresco had always been discounted because of the dating. Revolutions was published in 1543, two years after the completion of the fresco in 1541. However, closer investigation reveals (which is evidently more well known amongst astronomers than art historians) that Copernicus actually received the first copy of his book whilst on his death bed in 1543, at the age of 70 .

Born in 1473, Copernicus was almost exactly contemporary with Michelangelo (1475-1564), and information about his ideas and reputation had been growing and circulating from as early as 1500 . Even before Copernicus, early Renaissance writers such as Buridan (1297-1358), Oresme (1323-82) and Cusanus (1401-64) had already considered similar ideas about the motion of the earth and a stationary sun and Copernicus acknowledged this in his Preface to Revolutions in 1543. Leonardo da Vinci also speculated that 'the sun does not move' (Notebooks, vol. 2, 152). Copernicus was invited to give talks in Rome in 1500 (when Michelangelo was also in Rome) and other publications such as the Commentariolus (1514) and the Letter against Werner (1522) circulated long before the publication of Revolutions (and the conception of the fresco). There is a great deal of additional evidence (for example comments made by Martin Luther) that Copernicus' ideas about the sun as the centre of the universe were circulating widely in the 1530's, if not the 1520's.[12] It thus becomes clear that (since it was not necessary then as now for anyone actually to read Revolutions in order to grasp the heliocentric idea) it would have been very unlikely for Michelangelo not to have heard of Copernicus and his ideas.

Copernicus' heliocentric theory thus originated well before the time of its publication (and his death) in 1543, as he himself explains in his preface. Copernicus' fame had spread and had been widely recognized as a leading astronomer for many years. His early fame was also evidenced in art since he is allegedly portrayed in Giorgione's painting of the Three Philosophers (which Giorgione painted in 1509, assisted by Sebastiano del Piombo - who also, coincidentally, helped Michelangelo in the early stages of preparations for the painting of the Last Judgment). The first reference to a commission for the Last Judgment was also made by Sebastiano, in July 1533. He wrote to Michelangelo that the Pope (Clement VII who was also a Medici and had known Michelangelo since childhood) had plans for a grand design in the Sistine Chapel.

\section{Dating of the Last Judgment and Revolutions}

Short of the discovery of handwritten notes by the artist, confirming awareness and influence of Copernican heliocentricity in the design of the Last Judgment, it might be difficult conclusively to prove a direct link. The above evidence may suggest that 'on the balance of probabilities' this is so. However, what appears to support the argument 'beyond reasonable doubt', making Copernican influence very clear is that at exactly the time of the commission of the painting, Pope Clement VII specifically requested that Copernicus' theories 'concerning the motion of the earth' should be explained to him at a special lecture to a group of dignitaries in the garden of the Vatican in June 1533. This event was recorded by the lecturer, Albert Widmanstadt inside the cover of a precious manuscript that the Pope gave him to mark the occasion:

'Clement VII presented this codex to me, AD 1533 after I had, in the presence of Fra Ursino, Cardinal Joh. Salviati, Joh.Petrus Bishop of Viterbo and Matthias Curtius, medical physician, explained to him in the garden of the Vatican, Copernicus' teaching concerning the motion of the earth. 
Albertus Widmanstadius'.[13]

Widmanstadt (who coincidentally was the protégé of Egidio da Viterbo who had advised Michelangelo on the painting of the Sistine ceiling) was a colleague of Theodoric of Radzyn, the representative of Copernicus' chapter of Varmia in Rome, so a direct link is easily traceable between Michelangelo and Copernicus at the time of the commission of the Last Judgment. The dating of the Vatican lecture can be secured by the reference to Johannes Petrus, Bishop of Viterbo since we know this appointment was made in summer 1533. Salviati, also present, was a close friend of Michelangelo and the date ' 6.33 ' on the manuscript suggests a date of June 1533. It is also well documented (Letter from del Piombo to Michelangelo dated 17 July 1533) that the Pope was then about to give Michelangelo a contract 'for such as thing as you have never yet dreamed of'. Michelangelo was in Rome until the end of June 1533 when he left for his last visit to Florence. Clement VII was in Rome that summer until he left in September on his way to France, during which time he met Michelangelo near Pisa to discuss the commission for the fresco (22 September 1533). So the Pope commissioned the fresco right after he had had Copernicus' heliocentric hypothesis explained to him by a professional lecturer with direct and traceable links to Copernicus himself.

Michelangelo's early drawings for the fresco suggest a circular design and astronomical references,[14] and further evidence exists of Vatican interest in Copernican astronomy at this time. The famous letter of Cardinal Schoenberg to Copernicus in 1536 makes it absolutely clear that Copernicus' hypothesis had been regarded as common knowledge for some time before 1536, that his talent was recognized by the Catholic Church and that the Vatican itself was urging publication. The letter appears to be an urgent request for further information as the painting of the fresco got underway in summer 1536. Schoenberg wrote: 'Several years ago word reached me ... I had learned that you had formulated a new cosmology; you maintain that the earth moves, that the sun occupies the most central place in the universe.... I entreat you to communicate this discovery of yours to scholars.... (Cardinal Schoenberg, 1536)'.[15] This strongly suggests 'approval' rather than mere 'knowledge' in Vatican circles in the 1530s. The Narratio Prima (published by Rheticus in 1540, followed by a second edition in 1541), also publicized the heliocentric theory. Clement VII had died by this time but the next Pope, Paul III Farnese (who had also grown up in the Medici household in Florence) supported both the fresco and the publication. In fact he was, significantly, the very person to whom Copernicus' Revolutions was dedicated in 1543. Considering the implication of a dedication and the strict application of the papal imprimatur at the time, tacit approval of the ideas (even though presented as hypothesis by the publisher Osiander) is indicated. This mass of evidence, culminating with the documentary evidence of the manuscript, although it cannot be conclusive, clearly points 'beyond all reasonable doubt' to the probability that the hypothesis is not mere speculation.

Although illustrations of the fresco prior to the cleaning and restoration in the early 1990's show it with a 'dark and desperate' atmosphere, caused by smoke from the candles, the cleaned and restored fresco is amazingly lighter and brighter. Contemporary copies (such as that by Martinus Rota, 1569) demonstrate that this was much closer to the original state of the fresco and thus clearly fits in with the concept of sun and light symbolism in the fresco. [16]

A summary of key dates - relating both to Michelangelo, Copernicus and the fresco itself, demonstrates significant overlap and coincidence (Table 1). Michelangelo was nurtured on Catholic views of Christ as the light (sun), imbued with Ficino and Dante and then commissioned to paint what was traditionally a cosmological subject at exactly the time that the theories of Copernicus (himself imbued with Italian Renaissance and neoplatonic thought) were attracting huge attention in the Vatican. It is vital that this cosmological interpretation should be given proper consideration and not dismissed because of misconstrued dating.

To return to the concept of the central point of the universe, it is interesting to consider what might be the central point in Michelangelo's design. A formal visual analysis of the painting itself can reveal this, since in order to obtain the circularity of the design on such an immense area (the wall is over 17 metres high), a device such as a rotating plumb line would have been used. Surprisingly, the centre of both the circular movement and the focus of diagonal lines does not lie on Christ's head or heart, but is evidently lower down. The centre of the design is actually focussed on Christ's right thigh. A reason for this is to be found in the book of Revelation, 19:16 which reads - ' ... and on his vesture and on his thigh was a name written, KING OF KINGS and LORD of LORDS. The next verse significantly begins '.. and I saw an angel standing in the sun ...'. Thus Christ is depicted as Michelangelo viewed him - King of Kings and Lord of Lords, the Sun the centre of the universe.

\section{Conclusions}

Copernicus' heliocentric theory seems, in the 1530 s, to have acted as a precipitating factor to cause a number of existing concepts to fall into place. His scientific thinking appears to have been absorbed into popular thinking and it was no more necessary for those who were interested to read his actual book, anymore than many nowadays who talk about general relativity and black holes have actually read anything by Einstein. It should be remembered that it was not until 1616, over 70 years since its first publication, that Copernicus' Revolutions was placed on the Index of Prohibited Books. The transition from the flat earth concept (with Jerusalem as centre) to geocentric, haidocentric, heliocentric - and more recently galactocentric and now a-centric (expanding with no real centre) views of the universe all add to our understanding and the importance of consideration of humanity's place in the universe. Due to 
Copernicus' theory, the central position of humanity, in a geocentric universe, had been displaced from its key location but surely the idea of placing God personified as the sun at centre was far more logical instead. In a view characterised by its elegant simplicity, this concept appears to be most logical. Lack of concrete evidence (the handwritten note) does not necessarily render a thing untrue. After all, Copernicus was unable to prove that the earth travelled around the sun.

The heliocentric concept of the universe which placed a spherical Earth in a Sun-centered system proposed an entirely different approach to astronomy which was fundamentally to change mankind's outlook on the universe. The resultant difficulties of placing Heaven, Earth and Hell in their relative physical and symbolic positions had previously been very straightforward. The new ideas were to lead eventually to the Church's condemnation - but not, it must be remembered until 1616, much later than the time at which Michelangelo was working on his fresco of the Last Judgment. Although Copernicus' theory was later condemned, when the wider implications were acknowledged following the work of Galileo, during the 1530s-40s this was quite simply not the case. At the time that Michelangelo was painting his great fresco, the heliocentric theory appears to have generated more interest and support from the Catholic Church than previously recognised. As interpreted by Michelangelo in his Last Judgment fresco, and linked to Copernican heliocentricity, the traditional analogy between Sun and Deity, at the centre of the universe, was vindicated at last.

Table 1. Lives of Copernicus and Michelangelo.

\begin{tabular}{|c|c|}
\hline Copernicus 1473-1543 & Michelangelo, 1475-1564 \\
\hline 1491-94 Copernicus at Cracow & 1496 Michelangelo in Bologna \\
\hline 1496-1503 C in Bologna, Rome & 1500 Michelangelo in Rome \\
\hline 1500 Copernicus in Rome & 1500-34 In Rome/Florence \\
\hline $\begin{array}{l}1514 \text { Copernicus' } \\
\text { Commentariolus }\end{array}$ & $\begin{array}{l}153317 \text { July 'a contract for such } \\
\text { a thing...' }\end{array}$ \\
\hline $\begin{array}{l}1514 \text { Fifth Lateran Council, } \\
\text { Copernicus' advice sought }\end{array}$ & $\begin{array}{l}153322 \text { Sept, Michelangelo, } \\
\text { Clement VII and Paul III meet } \\
\text { near Pisa }\end{array}$ \\
\hline $\begin{array}{l}1524 \text { Letter against Werner } \\
\text { circulating }\end{array}$ & 1533 'Bayonne' drawing of LJ \\
\hline 1531 Satires on Copernicus & 1534 'Buonarroti' drawing of LJ \\
\hline 1533 Lecture in Vatican (June) & $\begin{array}{l}1534 \text { Sept, Michelangelo returns } \\
\text { to Rome; Clement dies; }\end{array}$ \\
\hline 1536 Schönberg's letter & 1534 Paul III becomes pope \\
\hline 1539 Luther against Copernicus & $\begin{array}{l}1536 \text { painting commenced } \\
\text { (April/ May) }\end{array}$ \\
\hline 1540 Narratio Prima & 153617 Nov, Papal breve on LJ \\
\hline $\begin{array}{l}1541 \text { Second edition of } \\
\text { Narratio Prima }\end{array}$ & 154131 Oct, completion/unveiling \\
\hline 1542 Revival of Inquisition & 1542 Pauline frescoes commissioned \\
\hline $\begin{array}{l}1543 \text { Death, Revolutions } \\
\text { published }\end{array}$ & $\begin{array}{l}1543 \text { Superintendent appointed } \\
\text { to safeguard the frescoes }\end{array}$ \\
\hline $1544 / 45$ Opposition to & 1545 Opposition to Last \\
\hline Revolutions commences & Judgment commences \\
\hline
\end{tabular}

\section{Acknowledgments}

The present paper is a summary of work completed some time ago and thanks are expressed to the IAU (Symposium 260), the Conferences on the Inspiration of Astronomical Phenomena (INSAP), Journal of the History of Astronomy, the Science Publishing Group and others to enable me to present this work in various conferences and publications. Thanks are also due to Truman State University for publication of the complete text where ideas discussed here in brief are fully explained and explored (Shrimplin, V. 2000, Sun-symbolism and Cosmology in Michelangelo's Last Judgment, Sixteenth Century Essays and Studies, vol. 46 Kirksville Mo.: Truman State University Press, based on my doctoral thesis of the same title, 1991).

\section{References}

[1] Michelangelo Buonarroti, Last Judgment, fresco, Sistine Chapel, Vatican, Rome, painted 1536-41 (13.7 x 12.2 metres; 45 x 40 feet). Illustrations are available through the powerpoint presentation, reproduced on the IAU Symposium 260 conference website http://iaus260.obspm.fr/. Most works referred to (eg Michelangelo's Last Judgment itself) are well known and can be viewed in widely available source books or on the internet.

[2] For a good summary of Michelangelo and his works, see Linda Murray, Michelangelo, His Life, Work and Times (London: Thames \& Hudson 1984).

[3] Nicholas Copernicus, De Revolutionibus Orbium Coelestium, Nuremburg, 1543 (ed. J. Dobrzycki, London: Macmillan, 1968).

[4] Tolnay, Charles de, Michelangelo, 5 vols. (Princeton: Princeton University Press, 1943-60) vol 5: 49 and 122.

[5] See K. Lehmann, 'The Dome of Heaven,' in W. E. Kleinbauer, Modern Perspectives in Western Art History, New York: Holt, Rinehart and Winston, 1971, pp. 227-270.

[6] Cosmas Indicopleustes, Christian Topography (Vat. Gr. 699), cross-sectional diagram of the Universe, and depiction of the Last Judgment, sixth century. Vatican Library, Rome. Two out of the three surviving manuscripts were in Rome and Florence during the late fifteenth and early sixteenth century, where Michelangelo could have had access.

[7] It appears significant that the ancient heliocentric theory as proposed by Aristarchus of Samos was mentioned by Vitruvius in his famous Ten Books on Architecture, with which Michelangelo was undoubtedly familiar.

[8] For Dante see Dante Alighieri, The Divine Comedy, transl. A Mandelbaum, 3 vols. (New York: Bantam, 1984), especially Inferno 34 and the Paradiso.

[9] For Ficino and the neoplatonists, see in particular Marsilio Ficino, De Amore, Commentary of Plato's Symposium on Love (Dallas: Spring, 1985) Cassirer, Ernst, The Individual and the Cosmos in Renaissance Philosophy (Oxford: Blackwell, 1963).

[10] De Sole is reproduced in translation in A. B. Fallico and H. Shapiro (eds.) Renaissance Philosophy, New York: Modern 
Library, 1967.

[11] For Copernicus, see for example Kuhn, Thomas, The Copernican Revolution (Cambridge: Harvard University Press, 1957), also Edward Rosen, Three Copernican Treatises (New York: Octagon, 1971).

[12] See Koestler, A. The Sleepwalkers. A History of Man's Changing Vision of the Universe, Harmondsworth: Penguin, 1984 and Kuhn, T. S. The Copernican Revolution. Planetary Astronomy in the Development of Western Thought, Cambridge: Harvard University Press, 1957.

[13] Bayersiche Staats Bibliothek Munich, Codex Graecus Monacensis, 151, and see Ludwig von Pastor, History of the Popes, 24 vols., (London: Routledge \& Kegan Paul 1901-28)10:336 and 12:549, also Leopold Prowe, Nicholas
Copernicus (Berlin, 1883), 1:273.

[14] The 'Bayonne' drawing, 1533 shows a clearly circular design, whilst the Buonarotti drawing (1534) alludes to the Virgin Mary in accordance with Revelation 12 'a woman clothed with the sun and the moon under her feet, and upon her head a crown of 12 stars'.

[15] Schönberg's letter was included in the printed versions of Revolutions in 1543 .

[16] See Mancinelli F. et al., Michelangelo e la Sistina. La Technica, il restauro, il mito, (Rome: Palombi, 1990) for information on the cleaning and restoration. 